SHORT COMMUNICATION

\title{
A new forest vegetation type in Sri Lanka: Dry Canal-associated Evergreen Forest
}

\author{
A.H. Magdon Jayasuriya* \\ EML Consultants (Pvt) Ltd, 6/10, Rajamahavihara Road, Pitakotte, Sri Lanka.
}

Received: 24/04/2019 ; Accepted: 15/10/2019

\begin{abstract}
During the Kingdom of Polonnaruwa (11-14 ${ }^{\text {th }}$ Century $\mathrm{AD})$, irrigation infrastructure and agricultural development in Sri Lanka were at their zenith. Irrigation system also consisted of canals conveying water from the Mahaweli River to distant farmlands. One such irrigation canal, presently within the Somawathiya National Park (SNP), supplied water from the river to a cascade of small tanks and farmlands as far as Kalu Ganga that divides Polonnaruwa and Trincomalee Districts on the Mahaweli Left Bank. The perennial presence of water during use, and subsequent disuse of the canal for centuries, since the fall of the Kingdom, evidently has caused edaphic, hydrological, microclimatic, biological and ecological changes that seem to have transformed vegetation existed during pre-Polonnaruwa and Polonnaruwa Periods in this part of the dry zone. Along the present day ruins of this ancient irrigation canal exists a unique zone of forest vegetation which has not been hitherto identified or recorded. This special forest formation which is anthropogenic in origin is here described as a new forest vegetation type in Sri Lanka and named Dry Canal-associated Evergreen Forest (DCEF) which closely resembles a river forest (Dry Riverine Evergreen Forest (DREF)), which in contrast is a natural vegetation formation.
\end{abstract}

Keywords: Dry zone, Irrigation canals, Polonnaruwa Period, Somawathiya National Park, Vegetation classification.

\section{INTRODUCTION}

Beside Sri Lanka being a relatively small continental island, it is endowed with remarkable diversity of forest types, which are among the biologically richest forests in South Asia (Jayasuriya et al., 2006). Various authors have attempted to classify country's natural vegetation based on a variety of concepts such as climatic and geographical zones, morphology, phenology and dominance of species and their assemblages. A notable classification system was proposed by Jayasuriya et al., (2006), supplemented by a digital map for fourteen major terrestrial vegetation types in Sri Lanka. In this user-friendly classification, nine forest types, four grassland types and the sand dunes were named and described. However, in a comprehensive vegetation classification system, in addition to major natural vegetation types, minor types that are relatively local or less extensive, whether they are natural or anthropogenic in origin, should also be considered.

\section{Hydraulic civilization and anthropogenic impacts on dry zone vegetation}

Due to the hydraulic civilization (300 BC-1200 AD) during historical times, the natural landscapes of the dry zone were impacted in varying degrees in space and time. In consequence, most of the present day dry lowland forests are of secondary in origin. However, due to the innate ability to recover, the dry zone forests have restored themselves almost to the original stature in some instances (Jayasuriya et al., 2006). However, this has not been the rule in some highly modified landscapes as demonstrated in the present study. Retention of water in tanks and conveyance by canals apparently have changed the hydrology, soil-water relation and other microclimatic changes as manifested by development of local vegetation/forest associations or types.

\section{The Kingdom of Polonnaruwa $\left(11^{\text {th }}-14^{\text {th }}\right.$ Century AD)}

Trade and agriculture flourished mainly under the reign of King Parakramabahu the Great (1153-1186) with the development of a highly efficient irrigation system. Concurrently, the natural vegetation including forests underwent large scale clearing in favour of agriculture. Due to constant water circulation among dams, canals, tanks and farm lands and with absorption and transpiration of water, this region would have experienced moist and cool microclimatic conditions and further, the rise of water table and atmospheric humidity are presumed to have induced a favourable climate and environment for the people to live in this part of the dry zone in prosperity (Withanarachchi, 2015).

A part of this highly efficient irrigation system consisted of a canal (name unknown), deep within the SNP, that conveyed water from a upstream intake point on the Left Bank of the Mahaweli River almost to the Kalu Ganga that borders the northern boundary of the Polonnaruwa District. Estimated length of the canal is $13.6 \mathrm{~km}$ (Irrigation Department, 2018).

The Proposed Mahaweli Left Bank Lower Basin Development Project (Irrigation Department, 2018) has also considered the possibility of diverting water from upstream Mahaweli River up to Janaranjana Wewa Reservoir via this ancient canal that ran through the present 
SNP by resurrecting it to function as a new feeder canal. An Environmental Impact Assessment (EIA) for the total project that includes the construction of a new reservoir and development of a tank cascade system was conducted by EML Consultants Pvt Ltd and it was necessary to place high importance to impending environmental impacts in these least known parts of the SNP (EML, 2019). This ancient canal was tracked by an arduous tractor journey through Somawathiya hinterlands and the canal appeared to be a dug canal without stone reinforcements. Highly meandering status of the canal within the forest indicated breaching, evidently from centuries ago. Presently, the canal is shallow with a depth up to $1 \mathrm{~m}$, often less, sand-filled and with some sporadic water pools along its meandering course through dense forest. The width of the canal varied between 5 to $15 \mathrm{~m}$. Although this is the scenario in the dry season, when the Mahaweli River is in spate and the area being in close proximity to the river (direct distance 500 $600 \mathrm{~m}$ ) and the Flood Plains, the area evidently undergoes extensive flooding and hence become totally inaccessible.

\section{METHODS AND MATERIALS}

A study was conducted in this human-modified forest area located in a remote and inaccessible part of the SNP. The forest belt along the ruined canal was sampled by Gradsect (gradient-directed transect) method that was successfully employed in the National Conservation Review (IUCN \& WCMC, 1997) for rapid biodiversity assessment. The method essentially consisted of a series of 100 X 5m linear plots laid along a transect running through a given site (and along an altitudinal gradient, if available). Three $100 \mathrm{X}$ $5 \mathrm{~m}$ plots were surveyed during the limited time of about 2.5 hours in this remote section of the SNP in which wild elephants were in plenty. Site information such as GPS and vegetation characteristics, e.g. forest cover, canopy height, forest floor and water table were noted. All plant species (trees, shrubs and herbs) were provisionally identified and recorded in the field. Herbarium specimens of species requiring further examination and other important representative species were collected and preserved to be subsequently checked and deposited in the National Herbarium as vouchers of this study. In addition to compiling the species composition, rare species, endemic species, threatened status (Red List status) and vernacular names were obtained. In order to determine species density, all individual trees and shrubs measuring $10 \mathrm{~cm}$ or more DBH (Diameter at Breast Height) were recorded. The species dominance is expressed in terms of species density, a simple time-saving tool used to understand some aspects of forest dynamics. In order to compare DCEF with DREF three 100 X 5 plots previously investigated in the DREF in the Kaluganga riverine forests during this EIA were used.

\section{RESULTS AND DISCUSSION}

\section{Ancient irrigation systems and their influence on Somawathiya natural vegetation}

During the Polonnaruwa Period, the system of irrigation that operated in relevant parts of the Somawathiya was totally supported by a feeder canal from the Mahaweli. The system is comparable to ancient tank cascade system that even prevails today in many parts of the dry zone and locally known as Ellangawa (Panabokke et al., 2002; MoA \& FAO, 2017). Although presently obliterated due to about 700 years of disuse, this irrigation system is presumed to have consisted of a hydrologically connected system of canals and tanks supporting a relatively large irrigated command area. The ruins of an ancient tank, now sand-filled and shrunk to about one hectare and holding permanent water to a depth of about half a metre, even in the heights of the dry season, was observed $\left(08^{0} 13^{\prime} 20.48^{\prime \prime} \mathrm{N}\right.$, $081^{0} 10$ ' 17.64 E') during this investigation (Figure 1). This indicated the possibility of existence of other tanks and canals connecting them. Archaeological evidence on ancient irrigation and agricultural infrastructure including implements and information on contemporary paddy varieties etc. are much in want.

\section{Human-influenced transformation of a dry forest into a wet forest}

When the canal was actively used for irrigation, possibly about 700 - 1000 years ago, evidently most of its supply areas would have been cultivated except for tank microcatchments presently detectable by the presence of patches of mature dry forests. Since the fall of the Polonnaruwa Kingdom in about $14^{\text {th }}$ Century, the intricate irrigation infrastructure evidently ceased to function. Due to the lack of use and maintenance, canal would have over-flown, breached and sand-filled thus resulting in the breakdown of the normal run; instead subject to meandering and dispersion. The rise of the water-table and increased accumulation of alluvium evidently modified the original dry forest ecosystem into a moist forest ecosystem with characteristics of 'riverine forest vegetation'. This succession of vegetation influenced by hydrological and edaphic transformation, resulted in remarkable changes in these human-modified vistas, not necessarily bringing back original vegetation patterns that existed during prePolonnaruwa Period.

\section{A new forest type in Sri Lanka - Dry Canal-associated Evergreen Forest (DCEF)}

The resultant canal-associated forest covered a linear zone of 30-50 $\mathrm{m}$ wide, along the canal path, as observed in the study area (Figure 2). The extant status of the new forest is apparently stable and in climax, developed during a period of about 700 years, and expected to be extremely sensitive to any possible future environmental changes. It can be ecologically categorized as a Climax forest of anthropogenic origin or anthropogenic climax forest.

Generally the plant biodiversity, in terms of number of species, endemism, rarity and status of threat, of this forest did not indicate any special features or uniqueness. It was the origin, assemblage of species, species dominance and special associated species that showed uniqueness of this forest type. Therefore, this forest is here described as a novel forest vegetation type in Sri Lanka and named as Dry Canal-associated Evergreen Forest (DCEF), a vegetation type not yet named and described by any vegetation ecologist in Sri Lanka. 


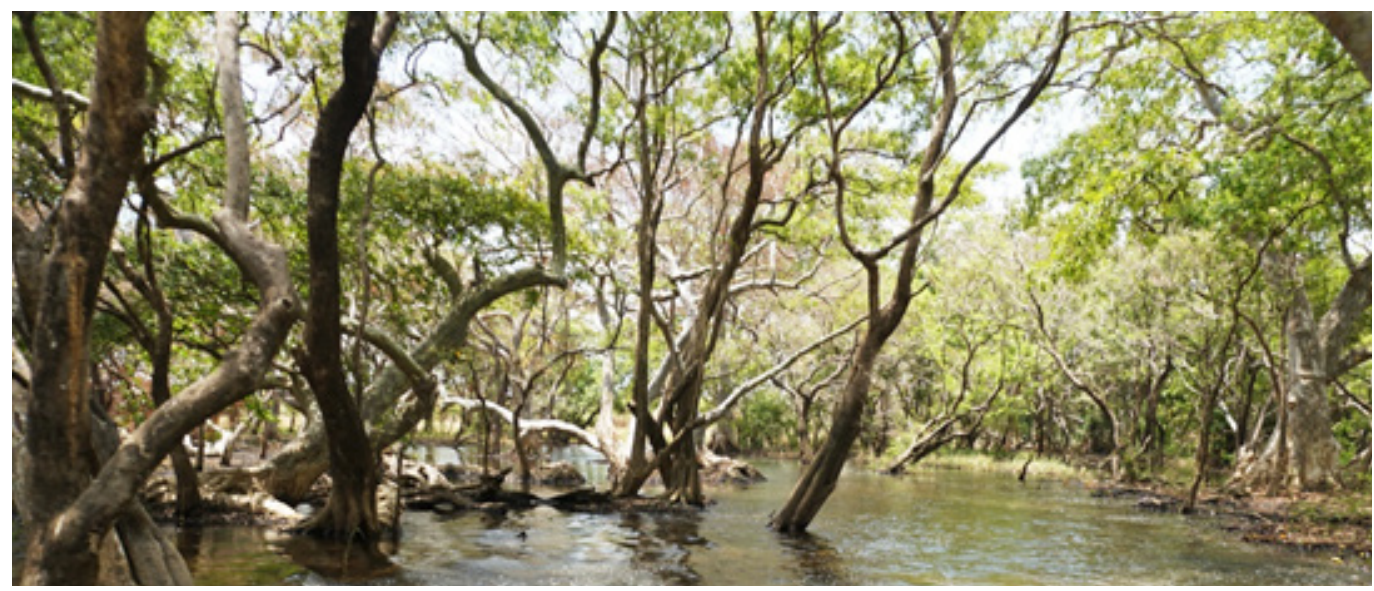

Figure 1: Remains of an ancient irrigation tank functional during the Polonnaruwa Period, is presently sand-filled and retains only up to one meter- deep water; this wetland habitat is colonized by a grove of Terminalia arjuna ('Kumbuk') trees, mimicking a river forest.

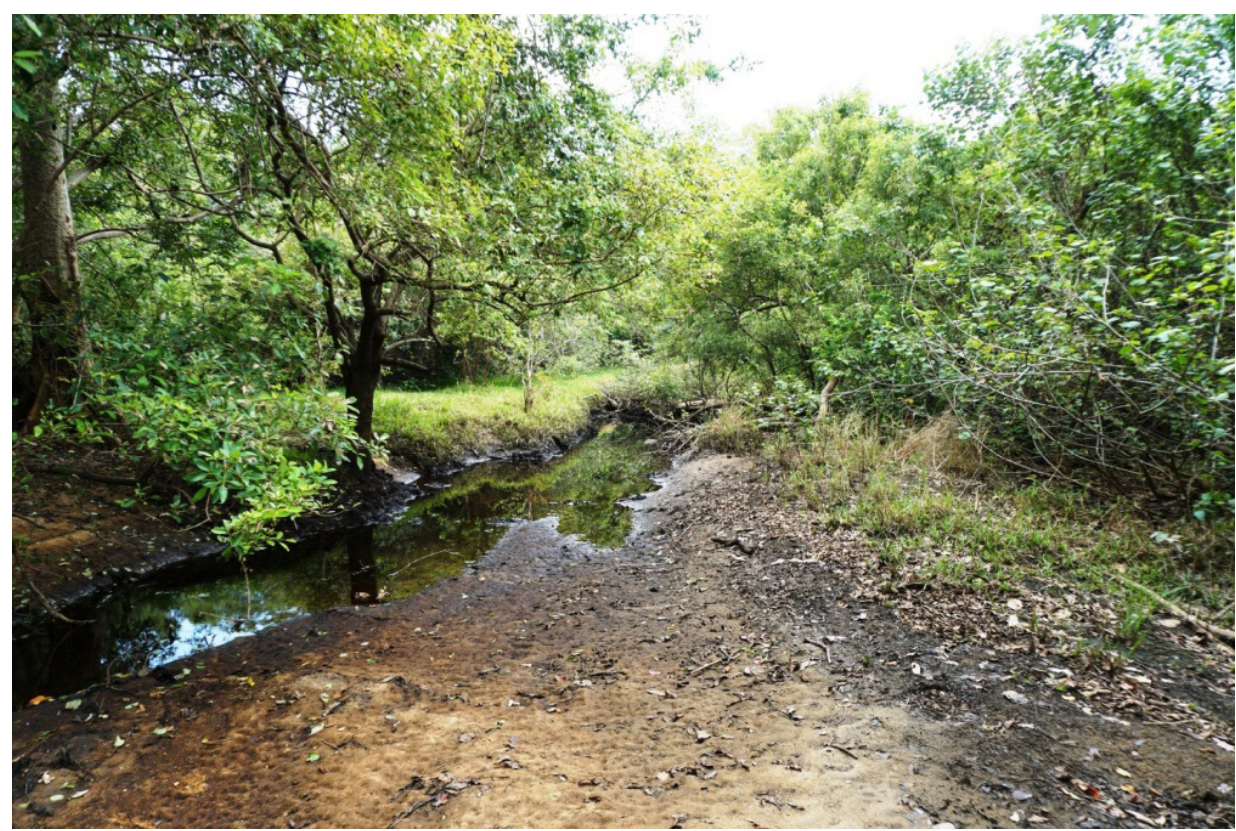

Figure 2: Deep within Somawathiya: Ruins of a nearly thousand year-old irrigation canal, now breached, dispersed, sand-filled and meandering in the forest and with sporadic pools of water (in dry season). The presence of water, before and after the canal was abandoned, possibly over 700 years ago, has induced the development of a wet forest, Dry Canal-associated Evergreen Forest, a newly recognized forest type in Sri Lanka.

Plant biodiversity: All plant species recorded are listed in Table 1. The scientific names of the species with their families, local names, endemism, threatened status at the national level (Red List Status), and their importance as medicinal resources have been included. Twenty four species in 23 genera and 15 families were recorded. There were no endemic species while 5 species were Nationally Threatened and 13 species were medicinally useful. 'Etkukuruman' (Tamilnadia uliginosa) was the only species that could be rated as rare in Sri Lanka.

During the present botanical survey of the proposed feeder canal and Kaluganga Reservoir areas within SNP, over 30 botanical specimens were gathered, preserved and subsequently deposited at the National Herbarium as voucher specimens. It is apparent that no botanical specimens have been collected previously in the Somawathiya prior to this survey.

Table 1: Plant biodiversity recorded in Dry Canal-associated Evergreen Forest (DCEF).

$\left(\right.$ General site GPS $=8^{\circ} 13^{\prime} 08.1^{\prime}$ N. $\left.81^{0} 10^{\prime} 42.1^{\prime} \mathrm{E}\right)$ 


\begin{tabular}{|c|c|c|c|c|}
\hline FAMILY (Synonym) Species & LOCAL NAME & $\mathbf{E}$ & TH-ST & M \\
\hline \multicolumn{5}{|c|}{ CELASTRACEAE (Hippocrateaceae) } \\
\hline Salacia oblonga $(10251)$ & Kotala-himbutu & & EN & M \\
\hline \multicolumn{5}{|l|}{ COMBRETACEAE } \\
\hline Terminalia arjuna & Kumbuk & & $\mathrm{LC}$ & M \\
\hline \multicolumn{5}{|l|}{ EBENACEAE } \\
\hline Diospyros malabarica & Timbiri & & $\mathrm{LC}$ & M \\
\hline \multicolumn{5}{|l|}{ EUPHORBIACEAE } \\
\hline Mallotus eriocarpus & Bulu-petta & & $\mathrm{LC}$ & M \\
\hline \multicolumn{5}{|l|}{ FABACEAE } \\
\hline Albizia ?chinensis (10244) & Kabal-mara & & VU & \\
\hline Derris scandens & Bokala-wel & & LC & \\
\hline \multicolumn{5}{|l|}{ Macroptilium lathyroides (10245) } \\
\hline \multicolumn{5}{|l|}{ LAMIACEAE (Verbenaceae) } \\
\hline Vitex leucoxylon (10247) & Nebada & & $\mathrm{LC}$ & M \\
\hline \multicolumn{5}{|l|}{ LECYTHIDACEAE } \\
\hline Barringtonia acutangula & Ela-midella & & $\mathrm{LC}$ & \\
\hline \multicolumn{5}{|c|}{ MALVACEAE (Sterculiaceae, Tiliaceae) } \\
\hline Berrya cordifolia & Hal-milla & & $\mathrm{LC}$ & \\
\hline Grewia orientalis (10248) & Wel-keliya & & $\mathrm{LC}$ & \\
\hline Hibiscus tiliaceus & Beli-patta & & $\mathrm{LC}$ & M \\
\hline \multicolumn{5}{|l|}{ MELIACEAE } \\
\hline Walsura trifoliolata & Kiri-kon & & $\mathrm{LC}$ & $\mathrm{M}$ \\
\hline \multicolumn{5}{|c|}{ PHYLLANTHACEAE (Euphorbiaceae) } \\
\hline Antidesma gaesembilla (10252) & Bu-embilla & & $\mathrm{LC}$ & \\
\hline Margaritaria indicus (10249) & Karawu & & VU & \\
\hline Phyllanthus polyphyllus & Kuratiya & & $\mathrm{LC}$ & M \\
\hline Phyllanthus reticulatus & Kaila & & $\mathrm{LC}$ & $\mathrm{M}$ \\
\hline \multicolumn{5}{|l|}{ POACEAE } \\
\hline Eragrostis japonica $(10270)$ & & & $\mathrm{LC}$ & \\
\hline \multicolumn{5}{|l|}{ RUBIACEAE } \\
\hline Ixora coccinea & Rat-mal & & $\mathrm{LC}$ & M \\
\hline Mitragyna parvifolia & Helamba & & $\mathrm{LC}$ & M \\
\hline Tamilnadia uliginosa (102242) & Et-kukuruman & & VU & \\
\hline \multicolumn{5}{|l|}{ RUTACEAE } \\
\hline Glycosmis pentaphylla (10246) & Dodan-pana & & $\mathrm{LC}$ & $\mathrm{M}$ \\
\hline \multicolumn{5}{|l|}{ SALICACEAE (Flacourtiaceae) } \\
\hline Casearia zeylanica (10250) & Wal-waraka & & $\mathrm{LC}$ & \\
\hline \multicolumn{5}{|l|}{ SAPOTACEAE } \\
\hline Madhuca longifolia & Mee & & NT & M \\
\hline
\end{tabular}

(SUMMARY: Total Families - 15; Total Genera - 23; Total Species - 24; Endemic species - 0; Nationally Threatened Species - 5 [EN - 1; NT - 1; VU - 3]; Rare species - 1; Medicinal species - 13)

E: Endemic

TH-ST: Threatened Status (National) (Ministry of Environment \& Department of National Botanic Gardens, 2012)

$\mathrm{CR}=$ Critically Endangered; $\mathrm{DD}=$ Data Deficient; EN=Endangered; LC=Least Concerned; NT=Near Threatened; VU = Vulnerable

M: Medicinal (Jayaweera, 1981-1982)

Plant classification and nomenclature follow Dassanayake et al., (1980-2000); updated according to APG III, 2009.

Number following species name indicates herbarium voucher specimen collected by the author. 
Special characteristics of DCEF: Table 2 indicates species densities of the DCEF, and DREF (for purposes of comparison), in order of dominance. Species assemblage of the DCEF appears to be special in that Vitex leucoxylon ('Nebada') was the most dominant species with a density of $52.7 \%$ followed by Terminalia arjuna ('Kumbuk') with a density of $19.8 \%$. Other notable dominants in this assemblage were Margaritaria indicus ('Karawu'), Tamilnadia uliginosa ('Et-kukuruman'), Barringtonia acutangula (Ela-midella') and Hibiscus tiliaceus ('Belipatta'). Although DCEF could exist elsewhere in Sri Lanka in association with irrigation canals that have been abandoned or currently functional, no previous systematic studies are known.
Dominance of Vitex leucoxylon ('Nebada'): This is commonly a moderate-sized tree occurring in association with tank peripheries, irrigation canals, villus and rivers in the dry and intermediate zones. However, it has relatively higher preference to (anthropogenic) irrigation components such as tanks and canals than (natural) rivers. This observation is supported by quantitative data gathered during this study that showed its dominance in DCEF (ancient irrigation canal) and complete absence in DREF (Kaluganga river). In comparison with 'Kumbuk' which apparently is the frequent dominant tree species in these water-associated habitats, it can be inferred that 'Nebada' is a relatively more secondary tree species and 'Kumbuk' is truly a primary species. For interested researchers, the

Table 2: Percentage Species Density in Dry Canal-associated Evergreen Forest (DCEF) and Dry Riverine Evergreen Forest (DREF).

\begin{tabular}{|c|c|c|c|}
\hline Species & Family & DCEF & DREF \\
\hline Vitex leucoxylon & Lamiaceae & 52.7 & \\
\hline Terminalia arjuna & Combretaceae & 19.8 & 33 \\
\hline Margaritaria indicus & Phyllanthaceae & 7.7 & $\mathrm{P}$ \\
\hline Tamilnadia uliginosa & Rubiaceae & 6.6 & \\
\hline Barringtonia acutangula & Lecythidaceae & 3.3 & 1.2 \\
\hline Hibiscus tiliaceus & Malvaceae & 3.3 & \\
\hline Albizzia chinensis & Fabaceae & 1.1 & \\
\hline Berrya cordifolia & Malvaceae & 1.1 & \\
\hline Casearia zeylanica & Salicaceae & 1.1 & $\mathrm{P}$ \\
\hline Madhuca longifolia & Sapotaceae & 1.1 & $\mathrm{P}$ \\
\hline Mitragyna parvifolia & Rubiaceae & 1.1 & 1.2 \\
\hline Salacia oblonga & Celastraceae & 1.1 & \\
\hline Diospyros malabarica & Ebenaceae & $\mathrm{P}$ & 8.5 \\
\hline Pterospermum suberifolium & Malvaceae & & 14.6 \\
\hline Derris parviflora & Fabaceae & & 7.3 \\
\hline Hydnocarpus venenata & Achariaceae & & 6.1 \\
\hline Crateva adansonii & Capparaceae & & 4.9 \\
\hline Syzygium cumini & Myrtaceae & & 4.9 \\
\hline Bauhinia racemosa & Fabaceae & & 2.4 \\
\hline Caturanegam spinosa & Rubiaceae & & 2.4 \\
\hline Cordia dichotoma & Boraginaceae & & 2.4 \\
\hline Dimorphocalyx glabellus & Euphorbiaceae & & 2.4 \\
\hline Diplodiscus verrucosus & Malvaceae & & 1.2 \\
\hline Drypetes gardneri & Putranjivaceae & & 1.2 \\
\hline Glenniea unijuga & Sapindaceae & & 1.2 \\
\hline Morinda correa & Rubiaceae & & 1.2 \\
\hline Phyllanthus polyphyllus & Phyllanthaceae & & 1.2 \\
\hline Stereospermum colais & Bignoniaceae & & 1.2 \\
\hline Ventilago madraspatana & Rhamnaceae & & 1.2 \\
\hline
\end{tabular}

DCEF - based on studies (three $100 \times 5 \mathrm{~m}$ plots) conducted at proposed feeder canal (ancient irrigation canal) within SNP. GPS $=8^{0}$ 13'08.1” N. 81010' 42.1” E.(EML, 2019).

DREF - based on studies conducted in Kalu Ganga riverine forest (three 100 x 5 m plots) at site of proposed Kalu Ganga Reservoir, bordering SNP. GPS $=8^{0} 15$ ' 48.5” N. 810 05'25.7” E. (EML, 2019).

$\mathrm{P}=$ Presence of only individuals less than $10 \mathrm{~cm} \mathrm{DBH}$.

For local names and other information on species, refer Table 1. 
use of MaxEnt software to model species occurrence within the island using distribution data of $V$. leucoxylon is recommended.

Presence of Tamilnadia uliginosa ('Et-kukuruman') in DCEF: This is a small tree species, although rarely recorded in Sri Lanka, occurs in association with open savanna-type habitats. Its occurrence in the dense forests of DCEF indicates the past existence (perhaps over 700 years ago) of Savanna or Savanna-related ecosystems in the present DCEF areas and the ability of this species to survive in extant modified habitats under forest cover. ' $\mathrm{Bu}$ embilla' (Antidesma gaesembilla), which was also recorded in DCEF, shows similar savanna affinities in its distribution in Sri Lanka. During our trek, small patches of Savannatype vegetation were noted on upland habitats, with signs of recent fires, a common occurrence in Savannas. The occurrence of Savanna Grassland in the Somawathiya area during the Pre-Polonnaruwa era is thought to be a possibility as they have been noted on Mahaweli Flood Plains area on the Mahaweli Right Bank on the opposite side of the Somawathiya (Jansen, 1982).

Affinities of DCEF with other forest types: The DCEF shows some close affinities with DREF, a major forest vegetation type in the dry zone (Jayasuriya et al., 2006). Both types are influenced by the presence of adequate water, mostly seasonal. Both forest types are considered hydrological and edaphic communities that are influenced by annual or regular floods, enriched by mineralrich alluvium, high water table and relatively higher atmospheric humidity as manifested by special vegetation morphology and species assemblages. Table 3 indicates contrasting features of the two forest vegetation types that will ascertain the validity of the DCEF as a novel vegetation / forest type in Sri Lanka. A notable difference is that while Vitex leucoxylon ('Nebada') dominates the DCEF it was not recorded in DREF. Another difference, in terms of density, Terminalia arjuna ('Kumbuk') which dominates DREF has fallen to a distant second place in DCEF.

\section{CONCLUSION}

The conduct of the EIA provided an excellent opportunity to investigate botanical and ecological aspects in this back of beyond country, presently conserved in the SNP. Although the time available for this study was limited due to relative inaccessibility of the study area, very useful observations were made, considerable amount of data was gathered and some botanical specimens were also collected. The serendipitous discovery of a novel forest vegetation type in the Somawathiya hinterland will hopefully urge vegetation ecologists to search for such forests elsewhere in Sri Lanka, especially in association with human-engineered irrigation canals and perhaps tanks.

The study and the literature survey also revealed some interesting information on irrigation and agriculture existed during the Kingdom of Polonnaruwa. These anthropogenic influences resulting in a serial transformation of the natural biota during the Pre-Polonnaruwa, Polonnaruwa and post Polonnaruwa Periods along with archaeological aspects on contemporary irrigation, agriculture, cultural and sociological scenarios should be investigated in-

Table 3: Contrasting features of Dry Canal-associated Evergreen Forest (DCEF) and Dry Riverine Evergreen Forest (DREF).

\begin{tabular}{|c|c|c|}
\hline Characetristic & DCEF & DREF \\
\hline Origin & $\begin{array}{l}\text { Anthropogenic; irrigation canal constructed } \\
\text { and functional during } 11^{\text {th }}-14^{\text {th }} \text { Century and } \\
\text { then abandoned; in climax. }\end{array}$ & Natural; in climax (in undisturbed sites) \\
\hline Water flow & $\begin{array}{l}\text { Regulated and maintained when the canal } \\
\text { was is use; breached, diffused and meandered } \\
\text { after canal was abandoned }\end{array}$ & Unregulated natural flow \\
\hline Banks & Generally shallow with gentle gradients & $\begin{array}{l}\text { Mostly steep due to seasonal strong and } \\
\text { unregulated water flow }\end{array}$ \\
\hline Habitats and plant biodiversity & $\begin{array}{l}\text { Due to low gradient canal bank, habitat is } \\
\text { generally uniform; hence relatively low plant } \\
\text { biodiversity; soil saturated with water during } \\
\text { most parts of the year. }\end{array}$ & $\begin{array}{l}\text { Due to steep river banks more (horizontally } \\
\text { zoned) habitats are created; upper levels of soil } \\
\text { relatively dry; hence relatively higher plant } \\
\text { biodiversity }\end{array}$ \\
\hline $\begin{array}{l}\text { Vegetation morphology: Canopy } \\
\text { height and lower forest strata }\end{array}$ & $\begin{array}{l}\text { Canopy } 10-12 \mathrm{~m} \text {; low stature forest with } \\
\text { dense lower strata. }\end{array}$ & $\begin{array}{l}\text { Canopy } 20-25 \mathrm{~m} \text {; forest appears high and } \\
\text { luxuriant; lower strata lax }\end{array}$ \\
\hline \multirow{6}{*}{$\begin{array}{l}\text { Species dominance with } \\
\text { percentage species density }\end{array}$} & Vitex leucoxylon (52.7) & Terminalia arjuna (33) \\
\hline & Terminalia arjuna (19.8) & Pterospermum suberifolium (14. 6) \\
\hline & Margaritaria indicus (7.7) & Derris parviflora $(7.3)$ \\
\hline & Tamilnadia uliginosa (6.6) & Hydnocarpus venenata (6.1) \\
\hline & Barringtonia acutangula (3.3) & Crateva adansonii (4.9) \\
\hline & Hibiscus tiliaceus (3.3) & Syzygium cumini (4.9) \\
\hline
\end{tabular}


depth, and in concert, rather than in sectorial manner. In this regard vegetation ecologists and biologist will have a fascinating landscape with diverse ecosystems which have been impacted in the past by anthropogenic processes such as irrigation and agriculture. For archaeological researchers, the Somawathiya will be a haven with much history on aspects of irrigation, agriculture, cultural and religious development. The wildlife sector will have enhanced responsibility in conservation and promoting multidisciplinary research on this important National Park in the future. Much interesting information will then be revealed on the history of the Kingdom of Polonnaruwa.

\section{ACKNOWLEDGEMENTS}

I am thankful to Mr. Avanthi Jayatilake, Director and Dr. Shiranee Yasaratne, Managing Director, EML Consultants Pvt Ltd for inviting me, along with other members of the EIA consultant team, to work in this exercise. The interactions and inputs from fellow consultants were extremely beneficial. I am further thankful to Mr. K. Subramaniam, Project Director, Mahaweli Left Bank Lower Basin Project, Irrigation Department and his staff at Kantale for providing necessary information, support and accompanying the EIA team in the field.

\section{REFERENCES}

Angiosperm Phyllogeny Group (2011). APG III System.

Dassanayake, M.D., Fosberg, F.R. and Clayton, W.D. (Eds). (1980 -2000). Revised Handbook to the Flora of Ceylon, Vol. 1-14. Amerind, New Delhi.

EML Consultants (Pvt) Ltd. (2019). Environment Impact Assessment of the Mahaweli Left Bank Lower Basin Development Project. Department of Irrigation.

Irrigation Department (2018). Feasibility Study on Mahaweli Left Bank Lower Basin Development Project (Kinniya - Kantale Area), 152 pp.

Irrigation Department (2019). Ancient Irrigation.http:// www.irrigation.gov.lk, accessed on August 31, 2019.

IUCN \& WCMC (1997). Designing an optimum protected areas for Sri Lanka's natural forests, Forest Conservation Department, Ministry of Forestry and Environment, Battaramulla, 299 pp.

Jansen, M. (1982). The Lure of the Mahaweli. Loris 16(2): 84-90.

Jayasuriya, A.H.M., D. Kitchener, and C. M. Biradar, (2006). Portfolio of Strategic Coinservation Sites / Protected Area Gap Analysis in Sri Lanka. A Report prepared by the EML Consultants for the Ministry of Environment \& Natural Resources. 340 pp.

Jayaweera, D.M.A. (1981-1982). Medicinal Plants Used in Ceylon Vol. 1-5. National Science Council, Colombo.

Ministry of Agriculture and FAO (2017). The Cascaded Tank-Village System (CTVS) in the Dry Zone of Sri Lanka, 126 pp.

Panabokke, C.R., Sakthivadevel, R. and Weerasinghe, A.D. (2002). Evolution, present status and issues concerning small tank systems in Sri Lanka. IWMI, Colombo, 72 pp.

Withanachchi, C.R. (2015). Ancient irrigation system of dry and intermediate zones as revealed from ancient canals. Rajarata Unviversity Journal 3: 4-16. 